\title{
Celiakie - doporučený postup pro diagnostiku a terapiii u dětí a dospívajících
}

\author{
MUDr. Pavel Frühauf, CSc., ${ }^{1,}$, doc. MUDr. Jiří Bronský, Ph.D., ${ }^{1,}$, MUDr. Petr Dědek, Ph.D., ${ }^{1,4}$ \\ prof. MUDr. Jiří Nevoral, CSc. ${ }^{1,3}$, MUDr. Radana Kotalová, CSc. ${ }^{1,3}$, prof. MUDr. Josef Sýkora, Ph.D.1, , \\ MUDr. Natália Szitányi ${ }^{2,7}$, MUDr. Alena Šebková2, ${ }^{\text {, }}$ MUDr. Lubomír Zahradníček, \\ 'Pracovní skupina pro dětskou gastroenterologii a výživu České pediatrické společnosti \\ ${ }^{2}$ Odborná společnost praktických lékařů pro děti a dorost \\ 3Pediatrická klinika UK 2. LF a FN Motol, Praha \\ ${ }^{4}$ Dětská klinika FN a LF UK, Hradec Králové \\ ${ }^{5}$ Dětská klinika FN a LF UK, Plzeň \\ ${ }^{6}$ Klinika dětského a dorostového lékařství UK 1. LF a VFN, Praha \\ ${ }^{7}$ PLDD Praha \\ ${ }^{8}$ PLDD Plzeň
}

${ }^{9}$ Dětská klinika MN, Ústí nad Labem

\section{Shrnutí:}

1. Celiakie je imunitně zprostředkované systémové onemocnění vyvolané glutenem a jemu podobnými prolaminy u geneticky vnímavých jedinců, charakterizované různou kombinací klinických př́znaků za prítomnosti specifických protilátek, HLA-DQ2 nebo HLA-DQ8 haplotypů a enteropatí.

2. Celiakie má různorodý klinický obraz, ale může být i asymptomatická. Je třeba na ni myslet a provádět selektivní screening, nebot' je v populaci nedostatečně diagnostikovaná.

3. Neléčená celiakie může být spojena s vážnými zdravotními komplikacemi.

4. Mezi nejvýraznější symptomy celiakie u dětí patří gastrointestinální symptomy, neprospívání, porucha růstu a anémie z deficitu železa.

5. Mezi onemocnění jednoznačně asociovaná s celiakií v dětském věku patři diabetes mellitus 1. typu, juvenilní idiopatická artritida, IgA nefropatie, deficit sérového lgA, autoimunitní tyroiditida, autoimunitní hepatitida, Downův syndrom, Turnerův syndrom a Williamsův syndrom.

6. Základem diagnostiky v první linii u symptomatického pacienta je vyšetření celkového lgA a anti-TG2 ve třídě lgA. Další sérologické testy $v$ primodiagnostice pacientů bez IgA deficitu nejsou nutné a mohou být zavádějící. Negativita anti-TG2 u pacienta bez lgA deficitu diagnózu prakticky vylučuje. V době vyšetření však musí pacient konzumovat stravu s lepkem v dostatečném množství (alespoň $15 \mathrm{~g} /$ den).

7. Při opakované pozitivitě protilátek anti-TG2 je nutno diagnózu potvrdit biopsií, kterou indikuje dětský gastroenterolog. Diagnózu bez enterobiopsie stanovuje pouze dětský gastroenterolog na základě splnění všech kritérií.

8. U asymptomatických jedinců (asociovaných onemocnění a prvostupňových príbuzných) je doporučeno provést jako první vyšetření HLA-DQ2 a HLA-DQ8, pokud je dostupné. Při pozitivitě HLA je nutné vyšetření protilátek - viz bod 6. K potvrzení diagnózy u těchto pacientů je biopsie vždy nutná. Vzhledem k vysoké prevalenci HLA-DQ2 nebo HLA-DQ8 u pacientů s diabetem 1. typu je vhodné jako screeningové vyšetření provádět anti-TG2.

9. Pozitivita HLA-DQ2 nebo HLA-DQ8 genotypu je $v$ populaci velmi častá
(35-40\%). Jen malá část těchto pacientů však vyvine celiakii. Genetické vyšetření se proto nehodí k diagnostice celiakie a naopak se použivá k jejímu vyloučení. Negativita HLA-DQ2 a HLA-DQ8 diagnózu celiakie prakticky vylučuje.

10. Sérologické testy i vyšetření HLA mohou být falešně pozitivní i negativní z důvodu laboratorní chyby. Při přetrvávajícím podezření na celiakii nebo diskrepantních výsledcích je doporučeno vyšetření opakovat.

11. Léčba celiakie je založena na přísné celoživotní bezlepkové dietě. Při jejím zahájení je vhodná konzultace specialisty na bezlepkovou dietu. Noncompliance $k$ dietě hrozí zejména u starších adolescentů.

12. Zahájení bezlepkové diety před dokončením diagnostiky celiakie je zcela chybné.

13. Plošný screening celiakie není $\checkmark$ našich podmínkách opodstatněný. K cílenému screeningu jsou indikováni pacienti s definovanými symptomy, asociovanými onemocněními a príbuzní 1. stupně.

14. Délka kojení a věk v době zavedení lepku do výživy kojenců neovlivní riziko rozvoje celiakie v dětském věku. 


\section{Definice}

Celiakie (glutensenzitivní enteropatie) je celoživotní imunitně zprostředkované systémové onemocnění vyvolané konzumací lepku (glutenu) a príbuzných prolaminů u geneticky predisponovaných jedinců (1). Onemocnění je charakterizované variabilní kombinací různých klinických projevů, pozitivitou protilátek specifických pro celiakii, prítomností HLA-DQ2 nebo HLA-DQ8 haplotypů a enteropatiií. Imunitní reakce je príčinou léze sliznice tenkého střeva. Obsah lepku a príbuzných prolaminů je nejvyšší $\checkmark$ pšenici a v sestupném pořadí následují žito, ječmen a oves. Frakce lepku rozpustná v alkoholu je gliadin.

\section{Epidemiologie}

Všeobecně je udáváno, že v současné době manifestuje celiakii $1 \%$ populace na světě s převahou žen 2-3:1. Poměr diagnostikovaných a nediagnostikovaných je udáván 1:3-5 pro dětskou i dospělou populaci. $V$ posledních letech se ukazuje, že prevalence i incidence narůstají nejen kvůli lepším znalostem a diagnostickým možnostem, ale také díky faktickému vzrůstu počtu onemocnění, především mimostřevních. Incidence v Evropě je udávána od 0,1 do $3,7 / 1000$ živě narozených/rok a pro dospělou populaci 1,3-39/100000/rok (2-6). V České republice se předpokládá podle publikací ze začátku tisíciletí prevalence celiakie v rozmezí 1 :200-1:250, tj. 40000 až 50000 celiaků (7-9). Přesto je $v$ současné době diagnostikováno a dispenzarizováno nejvýše $15 \%$ z celkového počtu postižených (10).

\section{Faktory, které se podílejí na vzniku celiakie}

Celiakie je charakterizována (1):

1. genetickou predispozicí: HLA-DQ2 (cca $95 \%$ nemocných) nebo HLA-DQ8 (cca $5 \%$ ) v populaci je 35-40\% obyvatel s HLA-DQ2

nebo HLA-DQ8 - celiakií však onemocní pouze $1 \%$ populace,

2. vyvolávajícím faktorem - lepkem,

3. vysoce specifickou a senzitivní protilátkou - proti rekombinantní humánní tkáňové transglutamináze 2. typu (anti-TG2), která hraje centrální roli v patogenezi celiakie, protože potencuje imunogenicitu lepkových peptidů v tenkém střevě cestou deaminace.

Tabulka 1. Klinické formy celiakie

\begin{tabular}{|l|c|c|l|}
\hline Formy & Protilátky & Biopsie & Př́znaky \\
\hline klasická & pozitivní & pozitivní & gastrointestinální \\
\hline neklasická & pozitivní & pozitivní & mimostřevní \\
\hline subklinická (dřive tichá) & pozitivní & pozitivní & na prahu klinické detekce \\
\hline asymptomatická & pozitivní & pozitivní & žádné \\
\hline
\end{tabular}

\section{Klinické projevy}

Celiakie má několik forem (viz tabulka 1).

\section{Klasická forma onemocnění}

Pacienti s klasickou formou celiakie mají známky a symptomy malabsorpce - průjmové stolice, stetorhea, nechutenství (ev. zvracení) úbytek tělesné hmotnosti a porucha růstu. Tato symptomatologie je častější u dětí.

\section{Neklasická forma onemocnění}

Pacienti s neklasickou formou onemocnění nemají gastrointestinální symptomy. K projevưm patří:

- kostní a svalové projevy (u dětí především malý růst, osteoporóza)

- kožní a slizniční projevy (dermatitis herpetiformis Duhring)

- hematologické projevy (jediným príznakem celiakie může být hypochromní anémie nereagující na běžnou léčbu železem)

- projevy v oblasti reprodukce (pozdní menarche, amenorhea, spontánní potraty, infertilita)

- neurologické projevy (mozečková ataxie, periferní neuropatie)

- psychické (depresivní stavy, včetně endogenních depresí s těžkým průběhem a suicidálními tendencemi)

- různé (zvýšené jaterní enzymy, nevysvětlený úbytek tělesné hmotnosti, nevysvětlený únavový syndrom, dráždivý tračník)

\section{Subklinická celiakie}

Nevýrazné symptomy, které jsou na prahu klinické detekce.

4. Asymptomatická celiakie je nalézána většinou screeningem v rizikových skupinách, jedinci často mívají nevýrazné symptomy a ve skutečnosti patři do skupiny se subklinickou celiakií.

Potencionální celiakie nemá žádnou klinickou symptomatologii, má pozitivní protilátky a negativní biopsii (pozor na její adekvátnost). Tito pacienti nemají držet dietu, dokud není diagnóza biopticky potvrzena.
Refrakterní celiakie - malabsorpční symptomy přetrvávají nebo se vracejí spolu s atrofií klků navzdory prísné bezlepkové dietě trvající déle než 12 měsíců. Vyloučeny musí být jiné prričiny atrofie klků nebo maligní onemocnění. $\checkmark$ prípadě pozitivity protilátek specifických pro celiakii je třeba vyloučit především porušování bezlepkové diety. U refrakterní celiakie se pravidelně jedná o dospělé pacienty.

\section{Přidružená onemocnění}

S celiakií se sdružují především autoimunitní onemocnění. Výskyt celiakie u některých autoimunitních onemocnění je i více než 10x vy̌̌ší než v běžné populaci. Celiakie je často asymptomatická nebo její projevy mohou být překryty jiným onemocněním. Prevalence asociovaných onemocnění je uváděna u dětí 20,7\% a u dospělých 30,1 \% (11). Vyšší počet asociovaných onemocnění u dospělých je vysvětlován delší expozicí lepku. Je rovněž udáváno, že mezi těmi, kteří dodržuji dietu, je menší výskyt asociovaných chorob (12). Podle současných doporučení ESPGHAN (1) je u dětí a adolescentů s některými onemocněními (viz tabulka 2) spojeno zvýšené riziko výskytu celiakie. U ostatních onemocnění je prevalence výskytu celiakie mezi 0,5-1\%, tedy stejná jako pravděpodobná prevalence v běžné populaci.

\section{Maligní onemocnění a celiakie}

Maligní lymfom, tj. T-lymfom sdružený s enteritidou (Enteritis Associated T-Cell Lymphoma, EATCL) je nejvýznamnější komplikací celiakie a tvoří polovinu všech malignit nalézaných u ce-

Tabullka 2. Onemocnění asociovaná s celiakií

\begin{tabular}{|l|l|}
\hline Diagnóza & Celiakie \% \\
\hline diabetes mellitus I. typu & $3-12$ \\
\hline autoimunitní tyroiditida & 3 \\
\hline autoimunitní hepatitida & 13,5 \\
\hline deficit sérového IgA & 3 \\
\hline IgA nefropatie & 4 \\
\hline Downův syndrom & $0,3-5,5$ \\
\hline Turnerův syndrom & 6,5 \\
\hline Williamsův syndrom & 9,5 \\
\hline juvenilní idiopatická artritida & $1,5-2,5$ \\
\hline
\end{tabular}


liakie. Celková asociace všech nehodgkinských lymfomů s celiakií je však méně častá, než se dřive myslelo (relativní riziko je $\leq 10$ ).

\section{Diagnostika}

Diagnóza celiakie (1) je postavena na základních kritériích - enteropatie (nálezu atrofie klků, hyperplazie krypt a zvýšeného počtu intraepiteliálních lymfocytů $v$ době, kdy pacient konzumuje stravu obsahující lepek) v prítomnosti protilátek anti-TG2 a úplné klinické remisi onemocnění a vymizení protilátek při bezlepkové dietě.

- Diagnostiku u symptomatických pacientů zahajujeme vyšetřením protilátek specifických pro celiakii (viz tabulka 1).

- U vybraných asociovaných chorob (viz tabulka 2) a u asymptomatických jedinců zahajujeme diagnostiku vyšetřením HLADQ2 a HLA-DQ8, je-li to možné (dostupné), jinak též vyšetřením protilátek. Vzhledem k vysoké prevalenci HLA-DQ2 a HLA-DQ8 u pacientů s diabetem 1. typu je vhodné jako screeningové vyšetření provádět vyšetření protilátek.

- Diagnóza je definitivně potvrzena z bioptického vzorku sliznice tenkého střeva vyjma jasně definované skupiny dětských pacientů, u nichž lze stanovit diagnózu bez biopsie.

Nová doporučení ESPGHAN (1) poprvé uvádějí možnost neprovedení biopsie u specifické skupiny pacientů - viz dále odstavec „Kdy Ize stanovit diagnózu celiakie bez biopsie?"

\section{Protilátky specifické pro celiakii}

Stanovení protilátek specifických pro celiakii je v současné době nejspecifičtější metodou k vyhledávání pacientů. Všechna ostatní vyšetření včetně biochemických, hematologických a zobrazovacích mohou poskytnout patologické nálezy, ale jejich specificita je nízká, nebot podobné odchylky mohou provázet i jiná onemocnění prì malabsorpčním syndromu. Nezbytnou podmínkou diagnostického sérologického vyšetření protilátek je dostatečná konzumace lepku (alespoň $15 \mathrm{~g} / \mathrm{den}$ ) a vyšetření hladin imunoglobulinů.

- Největší přesnosti $v$ diagnóze celiakie dosahují protilátky ve třídě IgA proti rekombinantní humánní tkáňové transglutamináze typ 2 (anti-TG2) a endomyziu
(EMA), viz tabulka 3. Pozitivita protilátek může předcházet vývoj histologických změn $v$ tenkém střevě.

- Vyšetření protilátek se provádí v séru. V jiných biologických materiálech není validováno.

- V době do vyšetření protilátek musí být pacient na dostatečné zátěži lepkem. Snižený př́ijem lepku mưže vést k falešně negativnímu nálezu. Proto je zahájení bezlepkové diety před definitivním stanovením diagnózy celiakie hrubou chybou. Dưležitá je i anamnéza, nebot některé rodiny již dodržují bezlepkovou dietu jako součást svého životního stylu.

- Diagnostiku zahajujeme vyšetřením celkového $\lg \mathrm{A}$ a anti-TG2 ve třídě $\lg \mathrm{A}$. Použitíjiných protilátek nebo bloku „celiakálních protilátek" zahrnujících protilátky ve třídě lgG proti TG2, EMA i deamidovanému gliadinu (DGP), není v primodiagnostice u pacientů bez IgA deficitu doporučeno a může být zavádějící.

- Při lgA deficitu (pod 0,2 g/L) je nutno vyšetřit EMA a anti-TG2 (případně protilátky proti $D G P)$ ve třídě lgG.

- Při nálezu pozitivních protilátek má být pacient odeslán k dětskému gastroenterologovi.

- U symptomatických pacientů s nižšími hodnotami anti-TG2 (do 10násobku normy) a současné pozitivitě EMA je třeba provést biopsii. U nízkých titrů anti-TG2 a negativních EMA je třeba pacienta sledovat a s odstupem času anti-TG2 a EMA vyšetření opakovat.

- Mírná pozitivita anti-TG2 (přibližně do 3násobku normy) může být falešně pozitivní při autoimunitní hepatitidě, psoriáze, kardiologických onemocněních, některých infekcí (EBV), m. Down.

- Anti-TG2 může být také falešně negativní prì malé konzumaci lepku, u enteropatií ztrácejících bílkoviny, léčbě imunosupresivy apod. Při přetrvávajícím důvodném podezření na celiakii je možné vyšetření protilátek opakovat v intervalu 3-6 měsíců. Při potvrzené negativitě je třeba pátrat po jiné př́čině obtíží.

- Negativita protilátek dle výše uvedeného postupu při normální zátěži lepkem diagnózu celiakie prakticky vylučuje. V takovém prípadě již není doporučeno podnikat žádné další diagnostické kroky (enterobiopsie, vyšetření HLA apod.).
- Dřive vyšetřované protilátky proti nativnímu gliadinu (AGA) nemají v algoritmu diagnostiky celiakie již žádné místo. Nedoporučuje se je vyšetřovat pro jejich nízkou specificitu a senzitivitu.

- Při orientačním zachycení pozitivity protilátek anti-TG $\vee$ rychlém (bedside) testu je třeba potvrdit pozitivitu protilátek vyšetřením v laboratoři ze séra. Bedside test není diagnostickým vyšetřením, jeho negativita diagnózu nevylučuje a při přetrvávajícím podezření je třeba doplnit vyšetření ze séra.

Tabullka 3. Senzitivita a specificita protilátek (13)

\begin{tabular}{|l|c|c|}
\hline Protilátka & Senzitivita \% & Specificita \% \\
\hline $\operatorname{IgA-EMA~}$ & $>90$ & 98,2 \\
\hline $\operatorname{Ig}$ A-anti-TG2 & 96,4 & 97,7 \\
\hline $\operatorname{IgA-DGP}$ & $80,7-95,1$ & $86,3-93,1$ \\
\hline $\operatorname{Ig} G-D G P$ & $80,1-98,6$ & $86,0-96,9$ \\
\hline
\end{tabular}

EMA - protilátky proti endomyziu

anti-DGP - protilátky proti deamidovanému gliadinu

anti-TG2 - protilátka proti rekombinantní humánní tkáňové transglutamináze 2. typu

\section{Genetické vyšetření - určení}

\section{HLA-DQ2/DQ8 $(1,14)$}

HLA antigeny II. třídy jsou odpovědny asi za 40 \% vnímavosti k celiakii. Zbytek (60 \%) genetické vnímavosti je výsledkem neznámého počtu non-HLA genů, z nichž každý může přispívat ke vzniku onemocnění.

- HLA-DQ2 má 95\% pacientů s celiakií, většina ze zbývajících $5 \%$ pacientů má heterodimer DQ8. Přibližně 35-40\% zdravých lidí má také stejné haplotypy, celiakií však onemocní pouze $1 \%$ populace. Genetické vyšetření se proto nehodí k vyhledávání pacientů $s$ celiakií v neselektované populaci a k jejich rutinní diagnostice!

- Stanovení HLA-DQ2 a HLA-DQ8 je užitečným vyšetřením k vyloučení celiakie nebo ke zjištění, že diagnóza celiakie je vysoce nepravděpodobná při neprítomnosti obou markerů. Vyšetření by mělo být proto provedeno u nejistých diagnóz.

- U vybrané skupiny symptomatických pacientů, u kterých Ize neprovést biopsii (viz dále) je doporučeno vyšetřit HLA k posílení diagnózy. Budoucnost však ukáže skutečný význam stanovení HLA v této situaci.

- Vyšetření HLA-DQ2 a HLA-DQ8 může být falešně negativní např. v důsledku laboratorní chyby. Při negativitě a přetrvávajícím po- 
dezření na celiakii je proto vhodné genetické vyšetření opakovat. Při potvrzené negativitě HLA je třeba pátrat po jiné príčině obtíží.

- U asymptomatických jedinců s príidruženými onemocněními - viz tab. 2 a u príbuzných 1. stupně pacientů $s$ celiakií je $v$ rámci selektivního screeningu doporučeno začít vyšetřením HLA. Při pozitivitě HLA pokračujeme nadále stanovením protilátek a při jejich pozitivitě diagnostický postup dokončuje dětský gastroenterolog.

\section{Biopsie a histologický nález}

Nález enteropatie (atrofie klků, hyperplazie krypt a zvýšeného počtu intraepiteliálních lymfocytů $v$ době, kdy pacient konzumuje stravu obsahující lepek) je základním stavebním kamenem diagnostiky celiakie (1).

- Bioptické vyšetření k potvrzení/vyloučení celiakie je indikováno pouze v prípadě pozitivních protilátek.

- Pokud je z bioptického vzorku odebraného z jiného důvodu vysloveno podezření na celiakii, je nutné doplnit vyšetření protilátek. Pokud jsou protilátky negativní, je třeba pátrat po jiné príčině bioptického nálezu.

- Bioptický vzorek Ize získat sací kapslí zavedenou pod rtg kontrolou, optimálně z místa duodenojejunálního přechodu, nebo endoskopicky s tím, že je doporučeno odebrat z postpapilárního duodena 4 vzorky a z bulbu minimálně 1 vzorek.

- Změny střevní sliznice mohou mít i jinou príčinu nežlepek: alergii na bílkovinu kravského mléka, střevní infekce, imunodeficience (15), minimální změny odpovídající Marsh 1 mohou být u Crohnovy choroby, infekce Helicobacter pylori, bakteriálních a parazitárních infekcích, při užívání nesteroidních antirevmatik.

- V počátečních stadiích onemocnění nebo u velmi malých dětí může být slizniční léze okrskovitá a nemusí být biopticky plně zastižena.

- Také nedostatečně kvalitní bioptický vzorek může vést $k$ falešně pozitivní i falešně negativní diagnóze. V prípadě pochybností je doporučeno biopsii opakovat.

\section{Expoziční test lepkem}

Zátěžový test lepkem je prováděn při jakýchkoliv pochybnostech o pưvodní diagnóze celiakie. Nemá se provádět u dětí do pěti let
Tabulka 4. Klasifikace změn jejunální/duodenální sliznice dle Marshe/Oberhubera (1, 14, 16, 17)

\begin{tabular}{|l|l|l|l|l|l|}
\hline Typ & IEL* & Krypty & KIky & Hodnocení & Diagnóza \\
\hline 0 & norma & normální & normální & normální sliznice & normální nález \\
\hline 1 & zvýšení & normální & normální & infiltrativní léze & $\begin{array}{l}\text { nespecifický nález, pozitivita } \\
\text { protilátek činí diagnózu možnou }\end{array}$ \\
\hline 2 & zvýšení & hyperplazie & normální & hyperplastická léze & $\begin{array}{l}\text { při pozitivitě protilátek } \\
\text { jistá }\end{array}$ \\
\hline 3 & zvýšení & hyperplazie & atrofie & $\begin{array}{l}\text { 3a) parciální atrofie } \\
\text { 3b) subtotální atrofie } \\
\text { 3c) totální atrofie }\end{array}$ & $\begin{array}{l}\text { prí pozitivitě protilátek } \\
\text { jistá }\end{array}$ \\
\hline
\end{tabular}

*IEL = intraepiteliální lymfocyty - ESPGHAN (1) připouští jako dolní hranici pro infiltrativní typ léze počet > 25/100 epiteliálních buněk v jejunu, Oberhuber (16) udává počet > 40/100, Dickson (17) udává v tzv. modifikované Marsh-Oberhuberově klasifikaci hranici > 30/100 - IEL je tedy nutno vždy posuzovat po dohodě s príslušnou laboratoří, v našich podmínkách je obvykle používána hranice > 40/100.

Tabulka 5. Nejčastější symptomy celiakie u dětí

\begin{tabular}{|l|l|}
\hline Mimostřevní & Gastrointestinální \\
\hline anémie z deficitu železa refrakterní na léčbu & chronické bolesti břicha \\
\hline anorexie & chronický průjem \\
\hline dráždivost & chronická zácpa \\
\hline chronická únava & nadýmání \\
\hline malá postava & velké břicho \\
\hline neprospívání & zvracení \\
\hline váhový úbytek & zvýšené jaterní enzymy \\
\hline
\end{tabular}

a v pubertálním růstovém spurtu. Před zahájením testu by měl být znám výsledek HLA typizace. Je třeba, aby pacient měl dostatečný př́ijem lepku (alespoň $15 \mathrm{~g} /$ den). Během expozice je třeba sledovat autoprotilátky specifické pro celiakii. V prípadě přetrvávající negativity autoprotilátek a nepřítomnosti symptomů Ize považovat test za dokončený po dvou letech expozice lepkem. Sledování pacienta má však být delší, protože relaps onemocnění je možný v horizontu až několika let.

\section{Algoritmus diagnostického postupu u pacienta se symptomy podezřelými z celiakie (1)}

Na celiakii má být pomýšleno u dítěte a adolescenta především tehdy, pokud má některý z následujících symptomů - viz tab. 5.

K rutinní diagnostice celiakie nejsou indikováni pacienti, jejichž příznaky jsou vysvětlitelné jinou diagnózou včetně např. pacientů, kteří splňují kritéria pro funkční recidivující bolesti břicha či funkční zácpu, kteří nemají varovné příznaky a/nebo dobře reagují na konvenční terapii. Prevalence těchto funkčních onemocnění v běžné dětské populaci je vysoká.

První krok k diagnostice celiakie u pacienta se symptomy je stanovení anti-TG2-IgA (za současného vyloučení deficitu sérového $\lg \mathbf{A})$ - viz obr. 1.

\section{Kdy Ize stanovit diagnózu celiakie bez biopsie?}

U jasně definované skupiny dětských pacientů (1) Ize stanovit diagnózu celiakie bez provedení biopsie. Toto rozhodnutí může učinit pouze lékař s príslušným vzděláním v oboru dětské gastroenterologie a to na základě následujících kritérií:

1) jsou prítomny klinické symptomy - viz tab. 5

2) není prítomen IgA deficit

3) pozitivita anti-TG2 nad 10násobek normy

4) pozitivita EMA z jiného vzorku a ověření 10násobné pozitivity anti-TG2

5) je vhodné doplnit vyšetření HLA-DQ2 a HLA-DQ8

6) symptomy onemocnění musí ustoupit po bezlepkové dietě

\section{Algoritmus diagnostického postupu u vyšetření asymptomatického jedince s genetickým rizikem celiakie (1)}

Do této skupiny patří asymptomatičtí príibuzní 1. stupně pacientů s celiakií, pacienti s přidruženými autoimunitními onemocněními a rizikovými chorobami - viz tab. 2. U těchto jedinců se začíná stanovením HLA-DQ2 a HLA-DQ8 viz obr. 1. Pokud je průkaz HLA-DQ2 a HLA-DQ8 negativní, nemusí se rizikoví asymptomatičtí jedinci dále vyšetřovat. Pokud je HLA testování pozitivní (nebo nemůže být provedeno), vyšetrují se protilátky anti-TG2-IgA současně s vyšet- 
Obr. 1. Diagnostický algoritmus celiakie

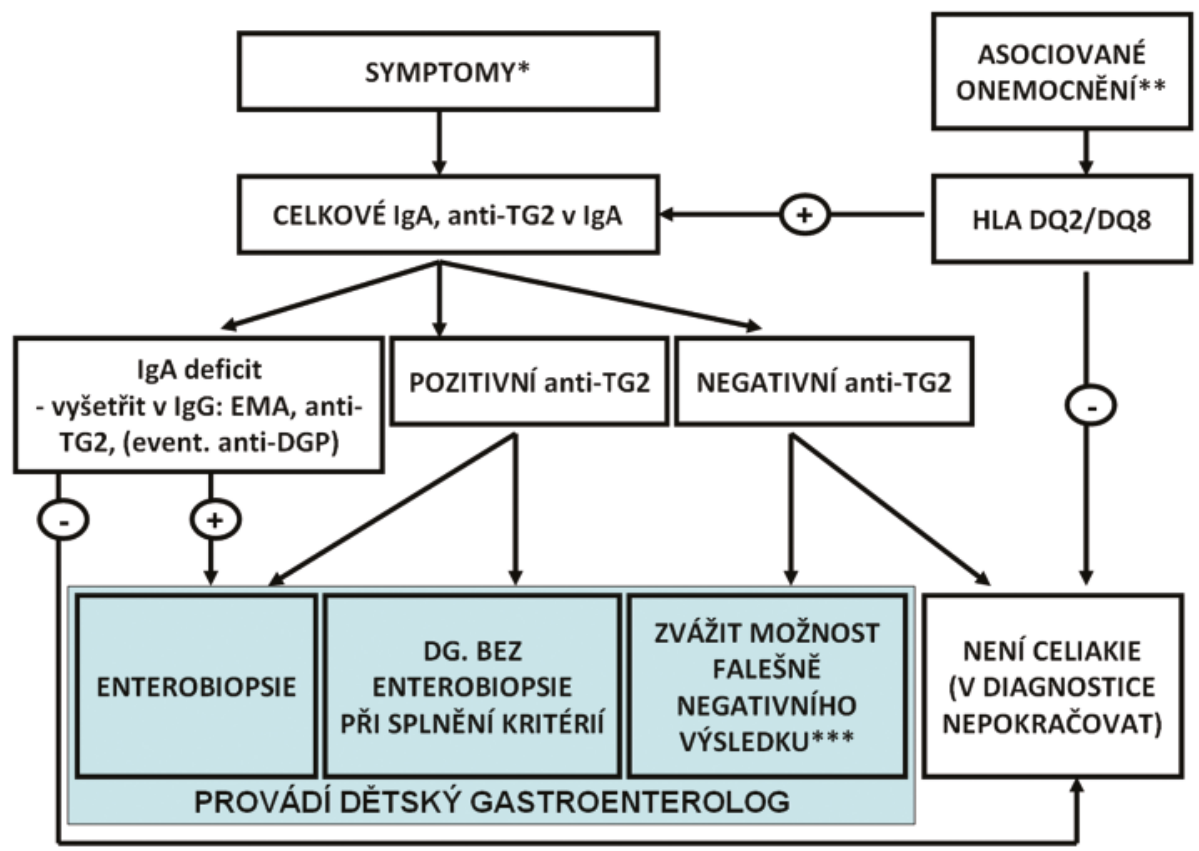

*Symptomy - viz tab. 5

**Asociovaná onemocnění - viz tab. 2. Vzhledem k vysoké prevalenci HLA-DQ2 nebo HLA-DQ8 u pacientů s diabetem 1. typu je vhodné jako screeningové vyšetření provádět anti-TG2.

***viz část věnovaná vyšetřování protilátek

řením celkového IgA. Jsou-li protilátky negativní a jedinec nemá deficit IgA, je diagnóza celiakie nepravděpodobná, nicméně onemocnění se může rozvinout později v dalších letech. Z těchto důvodů by se mělo testování protilátek provádět $v$ pravidelných intervalech. Doporučuje se testovat děti v intervalech 1-3 let a tak předejít rozvoji nerozpoznané celiakie se škodlivým vlivem na růst a vývoj dítěte. U dítěte HLA-DQ2 nebo HLA-DQ8 pozitivního, u kterého je mezi príbuznými 1. stupně celiakie, se onemocnění může rozvinout až po řadě let a proto je potřeba dítě sledovat minimálně do školních let. U diabetiků 1. typu $(18,19)$, i když je první sérologické vyšetření na celiakii v době diagnózy diabetu negativní, doporučuje se vyšetření opakovat $\checkmark$ pravidelných intervalech (cca po 1-2 letech). U jedinců s genetickým rizikem celiakie (asociovaná onemocnění, príbuzní 1. stupně), kteří mají symptomy uvedené $v$ tabulce 5 , postupujeme podle algoritmu pro symptomatické pacienty.

\section{Monitorace pacientů s diagnostikovanou celiakií}

Rodinám dětí s nově diagnostikovanou celiakií by měla být poskytnuta odborná konzultace týkající se problematiky bezlepkové diety. U prvostupňových príbuzných pacienta (sourozenci, rodiče) je doporučeno provést selektivní screening vyšetřením HLA-DQ2 a HLA-DQ8. Při nedostupnosti vyšetření HLA je doporučeno provést vyšetření anti-TG2 a celkového lgA.

Doporučení ESPGHAN (1), National Institute for Health and Care Excellence (20) a North American Society for Pediatric Gastroenterology Hepatology and Nutrition (21) jednoznačně neurčují, co při dispenzarizaci sledovat z hlediska možných nutričních deficiencí. Někteří doporučují v rámci dispenzarizace testovat i event. autoimunitní thyreoiditidu, bez udání frekvence vyšetření (22). Závěr práce, která se věnovala tomuto problému (23) je, že rutinní testování nutričních deficiencí a funkce štítné žlázy není efektivní, pokud nejsou při klinických kontrolách zjištěny poruchy růstu a udávány stížnosti na únavu.

Jako vhodné se zdá, po dosažení negativity autoprotilátek (mělo by nastat nejpozději do 12 měsíců od zahájení bezlepkové diety) jako projevu dodržování bezlepkové diety, jedenkrát ročně nemocného s celiakií vyšetřit v rámci dispenzarizace u pediatrického gastroenterologa, včetně podrobné anamnézy, posouzení dynamiky somatických parametrů a testovat dodržování diety prostřednictvím IgA anti-TG2 ( $v$ prípadě sniženého lgA i ve třídě lgG) s indikací dalších vyšetření až na základě subjektivních stesků a fyzikálního nálezu.

\section{Screening celiakie}

Plošný screening celiakie není v současné době doporučován.

\section{Cílený screening}

Celiakie je nadále v české populaci nedostatečně diagnostikovaná. Př́činou je změna fenotypu choroby v posledních desetiletích. Střevni príznaky dominují jen u malých dětí. U starších dětí, mladistvých a zejména u dospělých převládají mimostřevní příznaky. Nejdůležitější opatření ke zlepšení současného stavu je cílený screening zaměřený na rizikové skupiny (1). V dětském a adolescentním věku jsou k cílenému screeningu indikováni pacienti, u kterých jsou přitomny symptomy či onemocnění asociovaná s celiakií - viz tab. 2 a tab. 5, a př́buzní 1. stupně pacientů s celiakií. Dvoustupňový screening doporučuje u symptomatických pacientů v první etapě stanovení sérových protilátek anti-TG2-IgA a celkového IgA. Při selektivním deficitu IgA se stanoví anti-TG2-lgG. U asymptomatických pacientů (s asociovaným onemocněním nebo příbuzní 1. stupně) je doporučeno stanovit genotyp HLA-DQ2 a HLA-DQ8. Při jeho pozitivitě se pokračuje stanovením protilátek (podrobněji viz kapitola diagnostika).

Rozšiřrené možnosti cíleného screeningu u dospělých pacientů upravuje věstník MZ ČR (24)

Vytipování možného nositele onemocnění provádějí: praktičtí lékaři, praktičtí lékaři pro děti a dorost, ambulantní specialisté

\section{Zavádění lepku do výživy kojenců (25)}

Kojení a čas zavedení lepku do výživy kojenců nemají efekt na riziko rozvoje celiakie $\checkmark$ dětském věku. $\vee$ současné době se nicméně doporučuje zavádět lepek do stravy kojence $v$ malém (2 lžičky pšeničné mouky do zeleninového príkrmu nebo dva piškoty do ovocného př́krmu) a postupně vzrůstajícím množství společně s ostatními nemléčnými príkrmy - obvykle mezi ukončeným 4. a ukončeným 7. měsícem věku. Z praktického hlediska je tedy možno se držet $v$ současnosti platných doporučení PSDG ČPS (viz www.gastroped.cz - v sekci „Doporučené postupy") (26).

\section{Léčba (10)}

Celoživotní bezlepková dieta je jedinou kauzální terapií celiakie. Stanovení diagnózy 
celiakie a vyslovení požadavku bezlepkové diety znamená pro pacienta velkou psychickou zátěž. Úspěšné zavedení tohoto dietního režimu vyžaduje týmový prístup, který zahrnuje kromě pacienta, jeho rodinu, lékaře, nutriční terapeutku a zájmovou organizaci celiaků, kterou má pacient s celiakií vždy vyhledat (27). Účinnost bezlepkové diety předpokládá úplné vyloučení surovin, potravin a nápojů s obsahem obilovin (žita, pšenice, ječmene a ovsa).

Prolaminová frakce ovsa (aveniny) je menší a méně imunogenní než v ostatních obilovinách, ale oves je často kontaminován príměsí jiných obilovin (zejména ječmene) a k jeho kontaminaci může dojít také při výrobě. Přesto, že přibližně 95\% pacientů s celiakií může snášet oves, vždy u nového pacienta se začíná léčba bezlepkovou dietou i s vyloučením ovsa. Pokud pacient dosáhne remise onemocnění, je možné pod lékařským dohledem postupně zavádět i oves za pečlivého klinického a laboratorního sledování. Oves však nesmí být kontaminovaný jinými obilovinami obsahujícími lepek, což musí být ověřeno atestem. Běžný oves na trhu v ČR proto nelze doporučit jako součást bezlepkové diety.

Jako bezlepkové suroviny se použivají rýže, kukuřice, sója, pohanka, loupané proso - jáhly, amarant a brambory. Sója může vyvolat vzácně alergickou reakci. Laik príměs lepku v řadě potravin i jiných výrobků nepředpokládá (uzeniny, kečup, hořčice, kyprící prášky do pečiva, zmrzlina, pomocné látky v lécích a mnoho dalších výrobků). Hlavní produkt používaný jako prísada do řady výrobků je pšeničný škrob, který ale obvykle obsahuje stopy lepku.

Množství lepku schopné vyvolat autoimunitní odpověd’ a zánětlivé změny střevní sliznice je velmi rozdílné u jednotlivých nemocných. Doporučuje se, aby denní přijem lepku u celiaka byl nižší než 50 mg (28). U některých celiaků však již 10 mg lepku může být provázeno slizničními změnami (29). Proto je třeba, aby pacient omezil př́jem lepku v maximální míře. Jsou pro to další důvody: Tíže infiltrativních změn sliznice tenkého střeva je úměrná zbytkovému množství lepku v potravě (30). Obsah některých vitaminů (B1, B2, B12, D), minerálů (železa, vápníku, zinku, hořčíku) a vlákniny v potravinách bezlepkové diety může být nižší, než jsou doporučená množství, a podobně je tomu s celkovou energetickou hodnotou. Dodržování bezlepkové diety klade na pacienty velké finanční nároky. Př́znivý účinek bezlepkové diety se dostavuje většinou v průběhu několika týdnů. Význam bezlepkové diety je třeba zvlášt vysvětlit celiakům s lehkou formou choroby a při malých nebo chybějících subjektivních obtížích. Nejčastější príčinou neúspěchu bezlepkové diety je její neúplné dodržování.

\section{$\mathrm{K}$ dosažení vyvážené bezlepkové diety} vedou tyto kroky (31):

1. Úvodní edukace zkušeným dietologem, kontakt s pacientským sdružením.

2. Kontinuální sledování s cílem dosažení negativity protilátek a další dispenzarizací.

3. Ovoce a zelenina denně, střídat druhy.

4. Bezlepkové produkty s fortifikací železem a foláty.

5. Pseudocereálie (pohanka, rebarbora, slzovka, laskavec - amarant, špenát, čirok, merlík, proso, milička), které nahrazují vlákninu obsaženou v lepkových cereálních produktech.

6. Přirozeně bezlepková strava (sója, luštěniny, rýže, brambory, kukuřice, maso, ryby).

Legislativně je obsah lepku v potravinách řešen v Prováděcím nařízení komise (EU) č. 828/2014 ze dne 30. 7. 2014 o požadavcích na poskytování informací o neprítomnosti či sníženém obsahu lepku v potravinách spotřebitelưm (32). Tvrzení „bez lepku“ Ize použit pouze tehdy, neobsahuje-li potravina ve stavu, v němž je prodávána konečnému spotřebiteli, více lepku než $\mathbf{2 0} \mathbf{~ m g / k g}$ potraviny. Potraviny označené údajem „velmi nízký obsah lepku“ mohou obsahovat lepek v maximálním množství $\mathbf{1 0 0} \mathbf{m g} / \mathbf{k g}$. Oves obsažený v potravinách označovaných jako „bez lepku“ nebo „s velmi nízkým obsahem lepku“ musí být speciálně vyroben, prripraven a/nebo zpracován tak, aby bylo zamezeno kontaminaci pšenicí, žitem, ječmenem nebo jejich kříženci, přičemž obsah lepku v ovsu nesmí být vyšší než 20 mg/kg.

Pacientská sdružení s celostátní působností Sdružení celiaků České republiky (www. celiac.cz) a Společnost pro bezlepkovou dietu (www.celiak.cz) jsou organizacemi pacientů poskytující odborné a praktické informace a podávají rovněž kompletní přehled pomoci, kterou aktuálně poskytují zdravotní pojištovny pacientům s celiakií. Podle údajů VZP byl v roce 2014 poskytnut príspěvek na bezlepkovou dietu
4360 pojištěncům ve věku do 18 let, což odpovídá 0,47\% pojištěncům VZP ve věku 0-18 let.

Podrobné informace pro pacienty s celiakií jsou také uvedeny na www.gastroped.cz v sekci "Pro pacienty".

\section{Compliance $\mathrm{k}$ bezlepkové dietě}

Literární údaje uvádějí, že compliance je lepší, pokud je bezlepková dieta indikována ve věku pod čtyři roky (33), pacienti ve věku 12-14 let dodržují bezlepkovou dietu lépe než ve věku 15-17 let (34). Biopsie v době diagnózy a další sledování zvyšuje compliance (35). Pacienti zachycení na základě screeningu mají horší compliance než pacienti s klinickými obtížemi (36). Prediktorem dobré compliance bezlepkové diety je výborná školní integrace a fungující sociální zázemí (37).

\section{Diferenciállní diagnostika (38)}

Komplexní diferenciální diagnostika celiakie zahrnuje diferenciální diagnostiku jednotlivých symptomů onemocnění (průjem, anémie, porucha růstu, dermatitida apod.) a je nad rámec tohoto doporučení. Z praktického hlediska považujeme za vhodné zmínit některé diagnózy, které jsou v klinické praxi často s celiakií mylně zaměňovány:

Laktózová intolerance (intolerance laktózy může být součástí manifestace celiakie, kdy $\checkmark$ rámci poškození sliznice tenkého střeva je dočasně snížena aktivita enzymu laktázy, což je udáváno asi u poloviny pacientů s nově diagnostikovanou celiakií, takže zpočátku může být krátce nutná i dieta s omezením mléka), event. další poruchy absorpce mono a disacharidů. Laktózová intolerance mủže být př́tomna i u jiných gastrointestinálních onemocnění (akutní infekční gastroenteritida, idiopatické střevní záněty apod.) nebo v adolescenci jako první projev fyziologické hypolaktázie dospělých. Někdy je mylně nazývána „alergií na laktózu“.

Alergie na bílkovinu kravského mléka je onemocnění typické pro kojence a malá batolata. Obvykle se tedy vyskytuje v jiném věkovém období, než celiakie. Jen malé procento onemocnění (obvykle alergie časného typu) přetrvává do vyššího věku. Diagnostiku a léčbu provádíme podle doporučení PSDG ČPS (viz www.gastroped.cz - v sekci „Doporučené postupy“) (26).

Alergie na bílkovinu obilí (pšenice) a její diagnostika patří do rukou zkušeného alergologa. V zásadě je možno rozlišit alergii časného ty- 
pu (IgE mediovanou), při níž dochází k okamžité (časné) reakci na potraviny s obsahem pšenice a alergii opožděného typu (v rádu několika dnů). U časného typu alergie může být určitým prínosem vyšetření lgE protilátek proti lepku či bílkovině pšenice. Negativita protilátek však alergii nevylučuje, pozitivita ji jednoznačně neprokazuje. U obou typů alergií je k průkazu diagnózy nutný eliminačně-expoziční test. Před vyslovením podezření na tuto diagnózu musí být provedeno vyšetření anti-TG2 protilátek s negativním nálezem.

\section{Neceliakální glutenová senzitivita je} stav, který se projevuje u některých jedinců subjektivním ústupem nejrůznějších symptomů při vyřazení lepku ze stravy. Nejedná se

\section{LITERATURA}

1. Husby S, Koletzko S, Korponay-Szabó IR, Mearin ML, Phillips A, Shamir R, Troncone R, Giersiepen K, Branski D, Catassi C, Lelgeman M, Mäki M, Ribes-Koninckx C, Ventura A, Zimmer KP. ESPGHAN Working Group on Coeliac Disease Diagnosis; ESPGHAN Gastroenterology Committee; European Society for Pediatric Gastroenterology, Hepatology, and Nutrition. European Society for Pediatric Gastroenterology, Hepatology, and Nutrition guidelines for the diagnosis of coeliac disease. J Pediatr Gastroenterol Nutr. 2012; 54: 136-160.

2. Altobelli E, Paduano R, Petrocelli R, Di Orio F, et al. Burden of celiac disease in Europe: a review of its childhood and adulthood prevalence and incidence as of September 2014. Ann. Ig. Med. Prevent. Comunita 2014; 26: 485-498.

3. Whitacre CC. Sex differences in autoimmune disease. Nat. Immunol. 2001; 2: 777-780.

4. Mustalahti K, Catassi C, Reunanen A, Fabiani E, Heier M, McMillan S, et al. The prevalence of celiac disease in Europe: results of a centralized, international mass screening project. Ann. Med. 2010; 42: 587-595.

5. Kang JY, Kang AHY, Green A, Gwee KA, Ho KY. Systematic review: Worldwide variation in the frequency of coeliac disease and changes over time. Aliment. Pharmacol. Ther. 2013; 38: 226-245.

6. Mäki M, Mustalahti K, Kokkonen J, Kulmala P, Haapalahti M, Karttunen T, Ilonen J, Laurila K, Dahlbom I, Hansson T, Höpfl P, Knip M. Prevalence of Celiac disease among children in Finland. N Engl J Med. 200; 348: 2517-2524.

7. Kolek A, Vospělová J, Hermanová Z, et al. Celiac disease incidence in children and adolescents in Moravia, Czech Republic. J Pediatr Gastroenterol Nutr 2003; 36: 506-507R. 8. Kotalová R, Nevoral J, Valtrová V, et al. Prevalence celiakie mezi rodiči a sourozenci dětí s celiakií. Čes-Slov Pediatr 2002; 57: 415-418.

9. Vančíková Z, Chlumecký V, Sokol D, et al. The serologic screening for celiac disease in the general population (blood donors) and in some high-risk groups of adults (patiens with autoimmune disease, osteoporosis and infertility) in the Czech Republic. Fol Microbiol 2001; 47: 753-758.

10. Frič P, Keil R. Celiakie pro praxi. Med. praxi 2011; 8: 354-359. 11. Bottaro G, Cataldo F, Rotolo N, Spina M, Corazza GR. The clinical pattern of subclinical/silent celiac disease: An analysis on 1026 consecutive cases. Am. J. Gastroenterol. 1999; 94: 691-696.

12. Cosnes J, Cellier C, Viol S, Colombel JF, Michaud L, Sarles J, Hugot JP, Ginies JL, Dabadie A, Mouterde O, et al. Incidence of autoimmune diseases in celiac disease: Protective effect of the gluten-free diet. Clin. Gastroenterol. Hepatol. 2008; 6: 53-58. o celiakii, kterou je potřeba před stanovením této diagnózy vždy vyloučit (stanovením anti-TG2 protilátek) stejně jako alergii na bílkovinu obilí. Neuvážené zavedení bezlepkové diety může zastřít skutečnou diagnózu celiakie. Narozdíl od celiakie, která je celoživotní onemocnění, může být neceliakální glutenová senzitivita přechodným stavem. Není jasné, která z komponent obilných zrn spouští symptomy. Jedinou možností průkazu této diagnózy je dvojitě zaslepený eliminačně-expoziční test s lepkem, který je v podmínkách klinické praxe velmi obtížně proveditelný.

\section{Zkratky}

AGA - protilátky proti nativnímu gliadinu

13. Giersiepen K, Lelgemann M, Stuhldreher N, Ronfani L, Husby S, Koletzko S, Korponay-Szabó I and the ESPGHAN Working Group on Coeliac Disease Diagnosis. Accuracy of Diagnostic Antibody Tests for Coeliac Disease in Children: Summary of an Evidence Report. J Pediatr Gastroenterol Nutr. 2012; 54: 229-241.

14. Marsh MN. Gluten, major histocompatibility komplex, and the small intestine: a molecular and immunobiologic approach to the spektrum of gluten sensitivity. Gastroenterology. 102; 1992: 330-354

15. Walker-Smith JA, Guandalini S, Schmitz J, Schmerling DH, Visakorpi JK. Revised criteria for diagnosis of celiac disease. Arch Dis Child. 1990; 65: 909-911.

16. Oberhuber G, Granditsch G, Vogelsang $H$. The histopathology of coeliac disease: time for a standardized report scheme for pathologists. Eur J Gastroenterol Hepatol. 1999; 11(10): 1185-1194.

17. Dickson BC, Streutker CJ, Chetty R. Coeliac disease: an update for pathologists. J Clin Pathol. 2006; 59(10): 1008-1016. 18. Kordonouri O, Klingensmith G, Knip M, Holl RW, Aanstoot HJ, Menon PS, Craig ME. International Society for Pediatric and Adolescent Diabetes. ISPAD Clinical Practice Consensus Guidelines 2014. Other complications and diabetes-associated conditions in children and adolescents. Pediatr Diabetes. 2014; 15(Suppl 20): 270-278.

19. http://www.diab.cz/dokumenty/standard_dm1_12.pdf. 20. Downey L, Houten R, Murch S, Longson D. Guideline Development Group. Recognition, assessment, and management of coeliac disease: summary of updated NICE guidance. BMJ. 2015 Sep 2;351:h4513. doi: 10.1136/bmj.h4513. 21. Hill ID, Dirks MH, Liptak GS, Colletti RB, Fasano A, Guandalini S, et al. Guideline for the diagnosis and treatment of celiac disease in children: recommendations of the North American Society for Pediatric Gastroenterology, Hepatology and Nutrition. J Pediatr Gastroenterol Nutr. 2005; 40: 1-19. 22. Ventura A, Magazu G, Gerarduzzi T, Greco L. Coeliac disease and the risk of autoimmune disorders. Gut. 2002; 51: 897-898.

23. Wessels MM, van Veen II, Vriezinga SL, Putter H, Rings EH, Mearin ML. Complementary Serologic Investigations in Children with Celiac Disease Is Unnecessary during Follow-Up. J Pediatr.2015 Nov 4. pii: S0022-3476(15)01152-X. doi: 10.1016/j. jpeds.2015.09. 078.

24. Cílený screening celiakie (Metodický pokyn MZ ČR) Věstník MZ ČR, částka 3, 2011

25. Szajewska H, et al. (The PREVENTCD Study Group) Systematic review with meta-analysis: early infant feeding and
anti-DGP - protilátky proti deamidovanému

gliadinu

anti-TG2 - protilátka proti rekombinantní

humánní tkáňové transglutamináze 2. typu

EBV - virus Epstein-Barrové

EMA - endomyziální protilátky

ESPGHAN - Evropská společnost pro dětskou gastroenterologii, hepatologii a výživu

EU - Evropská unie

HLA - hlavní histokompatibilní komplex

IEL - intraepiteliální lymfocyty

IgA, IgG - imunoglobulin A, G

PSDG ČPS - Pracovní skupina pro dětskou gastroenterologii a výživu České pediatrické společnosti

VZP - Všeobecná zdravotní pojištơvna

coeliac disease-update 2015. Aliment Pharmacol Ther. 2015 41: 1038-1054.

26. Pracovní skupina pro dětskou gastroenterologii a výživu ČPS - Doporučení pro výživu kojenců a batolat. ČS pediatrie, duben 2014; S1/69: 1-47.

27. Case S. The gluten-free diet: how to provide eff ective education and resources. Gastroenterology 2005; 128(Suppl 1): S128-S134.

28. Catassi C, Fabiani E, Lacono G, et al. A prospective, double-blind, placebo-controlled trial to establish a safe threshold for patients with celiac disease. Am J Clin Nutr 2007; 85 160-166.

29. Akobeng AK, Thomas AG. Systematic review: tolerable amount of gluten for people with celiac disease. Aliment Pharmacol Ther 2008; 27: 1044-1052.

30. Catassi C, Rosini M, Ratsch IM, et al. Dose dependent effects of protracted ingestion of small amounts of gliadin in celiac disease children: a clinical and jejunal morphometrical study. Gut 1993; 34: 1515-1519.

31. Penagini F, et al. Gluten-Free Diet in Children: An Approach to a Nutritionally Adequate and Balanced Diet. Nutrients 2013; 5: 4553-4565.

32. http://eur-lex.europa.eu/legal-content/CS/TXT/?uri=CELEX\%3A32014R0828.

33. Högberg L, Grodzinsky E, Stenhammar L. Better dietary compliance in patients with coeliac disease diagnosed in early childhood. Scand J Gastroenterol. 2003; 38: 751-754. 34. Ljungman G, Myrdal U. Compliance in teenagers with coeliac disease-a Swedish follow-up study. Acta Paediatr. 1993; 82: 235-238.

35. Bardella MT, Molteni N, Prampolini L, Giunta AM, Bianchi P. Need for follow up in coeliac disease. Arch Dis Child. 1994; 70: 211-213.

36. Fabiani E, Corrao G, Barbato M, De Renzo A, Carella AM, et al. Compliance with gluten-free diet in adolescents with screening-detected celiac disease: a 5-year follow-up study. J Pediatr. 2000; 136: 841-843.

37. Errichiello S, Esposito O, Di Mase R, Camarca ME, Natale C, Limongelli MG, Marano C, Coruzzo A, Lombardo M, Strisciuglio P, Greco L. Celiac disease: predictors of compliance with a gluten-free diet in adolescents and young adults. J Pediatr Gastroenterol Nutr. 2010; 50: 54-60.

38. Kucek LS, Veenstra LD, Amnuychaeewa P, Sorrels ME. A Grounded Guide to Gluten: How Modern Genotypes and Processing Impact Wheat Sensitivity. Comprehensive Reviews in Food Science and Food Safety. 2015; 15: 285-302. 